\title{
TO LIVE BUT DIE INSIDE: A LAMENTABLE STATE OF MONTRESSOR IN "THE CASK OF AMONTILLADO"
}

\author{
Jesusa C. Francisco* \\ Department of English, Bulacan State University, Guinhawa Street, City of Malolos, Bulacan, Philippines
}

\begin{tabular}{|c|c|}
\hline ARTICLE INFO & A B S T R A T \\
\hline $\begin{array}{l}\text { Keywords: } \\
\text { Envy } \\
\text { Love deprivation } \\
\text { Morals } \\
\text { Self-esteem }\end{array}$ & $\begin{array}{l}\text { The enduring quality of "The Cask of Amontillado" makes it a timeless } \\
\text { classic in which researchers from different generations offer a variety of } \\
\text { subjective interpretations. This study aims to look closer to the story of "The } \\
\text { Cask of Amontillado" to reveal other underlying themes. The themes were } \\
\text { identified using content/textual analysis and a humanistic literary approach } \\
\text { in interpreting meanings. The themes discovered involve excessive self-esteem, } \\
\text { a penchant for prestige, lusting for another's good fortune (envy), and love }\end{array}$ \\
\hline $\begin{array}{l}\text { Article History: } \\
\text { Received: } 18 / 04 / 2021 \\
\text { Accepted: 08/11/2021 } \\
\text { Available Online: } \\
\text { 30/11/2021 }\end{array}$ & $\begin{array}{l}\text { deprivation. These themes, in a way, express the psychological needs of } \\
\text { humans reflected in Maslow's Hierarchy of Needs. Left unsatisfied, these } \\
\text { basic human needs (self-esteem, prestige, and love) led to the characters' } \\
\text { downfall because their thoughts and actions were inconsistent with ethical } \\
\text { conduct. Findings of the study may add to the existing interpretations of the } \\
\text { story, which primarily discuss and look into the various facets of its } \\
\text { overarching theme of revenge along with Montressor's mental condition. }\end{array}$ \\
\hline
\end{tabular}

2442-305X / (C) 2021 The Author, this is open access article under the (CC-BY-NC) license (https://creativecommons.org/licenses/by-nc/4.0/), DOI:10.19105/ojbs.v15i2.4563

\footnotetext{
* Corresponding Author:

Email address: jesusa.francisco@bulsu.edu.ph (J. C. Francisco)
}

\section{A. Introduction}

Classical literature never goes out of season, time and style because it meets the standards of artistic quality and prominence. It is immortal, thus accessible to anyone, just like the works of contemporary authors. ${ }^{1}$ Literary works of William Shakespeare, John Milton, and

\footnotetext{
${ }^{1}$ Syrithe Pugh, "Adonis and Literary Immortality in Pastoral Elegy," in Conversations: Classical and Renaissance Intertextuality, ed. Syrithe Pugh (Manchester: Manchester University Press, 2020), 179-229, https://doi.org/10.7765/9781526152688.
}

Edgar Allan Poe are timeless because of the universal themes they convey, which until now have a way of relating and connecting to the emotions of the readers like love, good versus evil, courage and revenge, among others.

The story "The Cask of Amontillado," written by Edgar Allan Poe and published in 1846, is still relevant because its theme which focuses on revenge has been played up in literary works, social media, and exhibited by 
people of authority and even ordinary individuals. Hence, even after 175 years have gone by, readers and researchers alike always find the new meanings and interpretations that have emerged over the years interesting and engaging. It is true that the author does not control analysis and interpretation of the text; instead, they are determined by the readers whose culture, background, generation, and religion contribute to the meaning created based on the literary piece presented. ${ }^{2}$ According to Read (as cited by Vooght \& Nemegeer), although the readers are referred to as the "consumers of interpretations," they, too, have their own interpretations of the text. ${ }^{3}$

Thus, in reading a text, one should not ask what the author wants to express, but simply what the words say which the readers should interpret. Just like the idea of deconstructionism which challenges the conventional interpretation and promotes an understanding of the text by exploring the underlying and not being restricted to the superficial meaning.

Edgar Allan Poe's "The Cask of Amontillado" is undeniably rich in imagery and symbolism in which various meanings or interpretations may be derived. According to DiSanza, a piece of writing must not be understood simply by looking

\footnotetext{
${ }^{2}$ Olivia Fialho, "What Is Literature for? The Role of Transformative Reading," ed. Anezka Kuzmicova, Cogent Arts \& Humanities 6, no. 1 (2019): 1-16, https://doi.org/10.1080/23311983.2019.1692532.

3 Edward De Vooght and Guylian Nemegeer, "Reading and Analysing Short Story Collections. An Empirical Study of Readers' Interpretation Process of Benni's II Bar Sotto II Mare," Language and Literature: International Journal of Stylistics, (2021), https://doi.org/10.1177/09639470211047817.
}

into the peripheral details but must be analyzed beyond the implied meanings represented by words, symbols, images, which direct the readers in identifying the underlying theme. ${ }^{4}$ Several themes of this literary piece have emerged from the study conducted by various authors from as early as the 1960s. Power relations, social status, and revenge were highlighted in the story. ${ }^{5}$

Revenge, which was the predominant theme in the story, was emphasized in the study of Elena Baraban in which she asserted that necessary information was provided in the text for readers to see Montressor's motive for murdering Fortunato, as opposed to the claim that his reason for revenge was not clear. ${ }^{6}$ Another angle was the condition of Montressor for carrying out such hideous murder. While others believed that Montressor was not in his right mind, committing the murder without stating the insult done to him, Cutitaru stated that all of Montressor's actions showed that he was not insane, as proven by his perfect crime, $^{7}$ resulting in his strong desire for revenge and sensitivity to insult. ${ }^{8}$ From the

\footnotetext{
${ }^{4}$ Raymond DiSanza, "On Memory, Forgetting, and Complicity in 'The Cask of Amontillado," The Edgar Allan Poe Review 15, no. 2 (2014): 194-204, https://doi.org/10.5325/edgallpoerev.15.2.0194.

${ }^{5}$ DiSanza, 202.

${ }^{6}$ Elena V. Baraban, "The Motive for Murder in 'The Cask of Amontillado' by Edgar Allan Poe," Rocky Mountain Review of Language and Literature 58, no. 2 (2004): 47-62, https://doi.org/10.2307/1566552.

7 Codrin Liviu Cuţitaru, "The Art of Dissimulation. The Good Christian vs. the Loyal Freemason," Philologica Jassyensia 13, no. 2 (2017): 203-9.

${ }^{8}$ Daniel Read, "The Five Games of Mr Edgar Allan Poe: A Study of Strategic Thought in 'The Purloined Letter,"' Rationality and Society 32, no. 4 (2020):
} 
point of view of Rehana Whatley, cultural and historical backgrounds were evident in the story. ${ }^{9}$ On the other hand, Cutitaru emphasized religious context as shown in the story's setting, which happened during the Venetian Carnival in Italy. ${ }^{10}$ Carnival was said to be a Catholic feast that is celebrated before the start of the Lenten Season.

Despite different interpretations drawn forth, evident was "revenge," which was the common theme among the literary works during the Renaissance period, and the one highlighted in most of the studies conducted on the analysis of "The Cask of Amontillado."11 Hence, the author looked into the other facets of the text which were not given so much attention, yet worthy of consideration.

Based on the foregoing discussion, the study attempts to explore other underlying themes of "The Cask of Amontillado," known as the best among the tales of horror written by Edgar Alan Poe. Further, it aims to perform textual analysis using humanistic approach in which the nature of human is made manifest through the words, actions and motivations projected by the characters.

369-401

https://doi.org/10.1177/1043463120961779.

9 Rehana Whatley, "Confession within A Confession: Poe's Brave New World in 'The Cask of Amontillado," Journal of Global Intelligence \& Policy 5, no. 7 (2012): 56-59.

${ }^{10}$ Cuţitaru, "The Art of Dissimulation. The Good Christian vs. the Loyal Freemason." 203.

${ }^{11}$ Caitlin Ray, Revenge (Essential Literary Themes) (Minneapolis, Minnesota: Abdo Publishing, 2015), 11-12.

\section{B. Method}

The study was qualitative research that used conventional content/textual analysis to identify the emerging themes/coding categories extracted from the text data. ${ }^{12}$ Content analysis involves the analysis of data and interpretation of its meaning, ${ }^{13}$ through "the systematic reading of a body of texts, images, and symbolic matter, not necessarily from an author's or user's perspective. ${ }^{14}$ Since the story is the primary source of information, the researcher read through and thoroughly the text, giving attention to the images, symbols, dialogs, and actions of the major characters. These served as the basis for identifying the themes or codes. Afterward, specific lines where both explicit and implied meanings could be derived were analyzed, interpreted, and quoted under each given theme or category.

Explanations of the quoted statements were then related to other ideas to offer the readers a wider range of critical perspectives. Moreover, in the process of analyzing the text and interpreting meaning, a humanistic literary approach was used. The humanistic approach emphasizes human beings, meaning, and actions. ${ }^{15}$ Humanistic

\footnotetext{
${ }^{12}$ Hsiu-Fang Hsieh and Sarah E. Shannon, "Three Approaches to Qualitative Content Analysis," Qualitative Health Research 15, no. 9 (2005): 1277-88, https://doi.org/10.1177/1049732305276687.

13 Margrit Schreier, Qualitative Content Analysis in Practice (London: SAGE Publications, 2012), 2.

14 Klaus Krippendorff, Content Analysis: An Introduction to Its Methodology (Thousand Oaks: SAGE, 2013), 392.

15 Michael Lewis-Beck, Alan Bryman, and Tim Futing Liao, The SAGE Encyclopedia of Social Science Research Methods (Thousand Oaks: Sage
} 
psychology attempted to revive the inclusion of "self" in psychology. ${ }^{16}$ However, it was the promotion of the positive "self" toward the realization of the person's full potential that was emphasized. For humanistic psychologists, the formation of one's personality is a work in progress "guided by intentionality, choice and hierarchical ordering of values."17

According to Aantoos, the humanistic self is "an engaged, involved, situated self, concerned and caring about the whole of Being, of which it is an interrelated manifestation." ${ }^{18}$ Nurturing one's relationship with self, others and their Creator and working on one's wellbeing are the basics of life. However, it was this side of the key player's personality that was seemingly lacking because the behavior he manifested digressed into less of being human, detached, unconcerned, unforgiving and vengeful. Hence, the study explored the different facets of the major characters, their actions, and reactions to situations, especially to provocations along with their demeanors which revealed their deviant human side.

\footnotetext{
Publications, Inc., 2004), https://doi.org/10.4135/9781412950589.

16 Christopher M. Aanstoos, "The Relevance of Humanistic Psychology," Journal of Humanistic Psychology 43, no. 3 (July 1, 2003): 121-32, https://doi.org/10.1177/0022167803043003010.

17 Andrew M. Bland and Eugene M. DeRobertis, "Humanistic Perspective," in Encyclopedia of Personality and Individual Differences, ed. Virgil Zeigler-Hill and Todd K. Shackelford (Cham: Springer International Publishing, 2019), 2, https://doi.org/10.1007/978-3-319-28099-8_1484-2.

18 Aanstoos, "The Relevance of Humanistic Psychology," 123.
}

\section{Results}

Aristotle once said that, "human is not only homo sapiens but also homo moralis." While it is true that we are all human beings endowed with intellect or intelligence, we, too, hold moral values, and this morality is what sets us apart from one another. In analyzing "The Cask of Amontillado," themes were identified according to the thoughts and actions of the characters that make them less human because of their "immorality" on the premise that morality tells what the "right" and "wrong" way to behave is. For instance, that one should be fair and not unfair to others. This was according to Haidt \& Kesebir, which Naomi Ellemers et al. cited in her study. ${ }^{19}$ According to the teachings of the Abrahamic religion, human beings are morally flawed, and although they are able to tell right from wrong, they still keep on straying. ${ }^{20}$ Here, both Montressor and Fortunato exhibited behaviors that were said to be wrong and unfair according to social norms.

\section{Excessive Self Esteem and Penchant for Prestige}

The fourth level in Maslow's hierarchy of needs is esteem, which is categorized into (1) esteem for oneself; and (2) the desire for prestige. This desire

\footnotetext{
19 Naomi Ellemers et al., "The Psychology of Morality: A Review and Analysis of Empirical Studies Published from 1940 Through 2017," Personality and Social Psychology Review 23, no. 4 (2019): 332-66, https://doi.org/10.1177/1088868318811759.

20 Amitai Etzioni, "The Moral Wrestler: Ignored by Maslow: I. Foundations," Society 54, no. 6 (2017): 512-19, https://doi.org/10.1007/s12115-017-02003.
} 
for prestige stems from the person's craving for social recognition and admiration. ${ }^{21}$ Truth be told, there is nothing wrong with wanting and even striving for prestige because it increases self-esteem. Besides, it is one of the psychological needs of humans that should be satisfied. However, it is the motivation, much more the means in which esteem is satisfied and fulfilled that makes it wrong. It is like saying that selfesteem (treated positively) results in the well-being of a person, but low selfesteem is linked with several psychological disorders. ${ }^{22}$ Oftentimes, low self-esteem works to one's disadvantage, worse doom, if not properly held in check.

In the opening statement of The Cask of Amontillado, there is an excerpt "The thousand injuries of Fortunato I had borne as I best could; but when he ventured upon insult, I vowed revenge, ${ }^{, 23}$ it was clear that insult was the reason that instigated Montressor to craft a perfect crime of murdering Fortunato.

On the other hand, Fortunato's response when Montressor was trying to rise him to the bait of consulting Luchesi whether or not it was the real Amontillado that he bought was, "As for Luchesi__"

\footnotetext{
21 Robert Reeves et al., "Desire for Fame: Scale Development and Association with Personal Goals and Aspirations," Psychology and Marketing 29, no. 9 (2012):

680-89, https://doi.org/10.1002/mar.20554.

22 Noémie Niveau, Boris New, and Marine Beaudoin, "Self-Esteem Interventions in Adults - A Systematic Review and Meta-Analysis," Journal of Research in Personality 94 (2021): 104-31, https://doi.org/10.1016/j.jrp.2021.104131.

23 Edgar Allan Poe, The Cask of Amontillado (Taiwan: Hyweb Technology Co. Ltd., 2011), 3.
}

"He is an ignoramus." ${ }^{24}$ Calling Luchesi an "ignoramus" just to show that he was better than or above anyone else displayed Fortunato's excessive esteem for his wine connoisseurship and his penchant for the prestige that led to his untimely and gruesome death. It may sound ironic, but excessive esteem indicates low self-esteem because a person who is secure of himself does not have to brag about his accomplishments or talents. Fortunato's strong desire to be acknowledged and recognized as the well-known connoisseur in wine was what Montressor used to hook and eventually made Fortunato fall into Montressor's trap. Montressor knew that in order to identify Fortunato's weakness, he had to know his greatest desire. As depicted in the following quote.

"He had a weak point-this Fortunato-although, in other regards, he was a man to be respected and even feared. He prided himself on his connoisseurship in wine." 25

Montressor used Fortunato's weakness to bait him and get his own way."As you are engaged, I am on my way to Luchesi. "If anyone has a critical turn, it is he. He will tell me ..."26 Not wanting anyone to be on a par with him or to be better than he was in wine tasting, Fortunato gave in to the prompting of Montressor, saying, "Luchesi cannot tell Amontillado from Sherry." ${ }^{27}$

\footnotetext{
${ }^{24}$ Poe, The Cask of Amontillado, 8.

${ }^{25}$ Poe, 3.

${ }^{26}$ Poe, 4.

${ }^{27}$ Poe, 4
} 
However, another interesting point to look into was also the need of Montressor for esteem to reassure himself that much like Fortunato, he was a wine expert. His desire to be acknowledged and respected by the other members of the noble group, especially Fortunato, whom he considered as his rival in wine connoisseurship, was strongly felt, just like "a wolf-- wanting to be part of the pack, respected by peers, and rivals." 28

According to Barkow, prestige increases one's status among the members of the social group to which they belong, ${ }^{29}$ because it makes a person gain respect, admiration, and, ultimately, high social rank. ${ }^{30}$ Unable to satisfy this need for recognition and acknowledgment might lead to negative emotions, such as unhappiness and maladjustment, which Montressor exhibited, shown by his evil plan. No human who is happy would ever think of something evil against their neighbors. In essence, this feeling of being recognized, accepted, and needed creates a person's self-worth and selfrespect $^{31}$ which Montressor earnestly desired but never obtained.

\footnotetext{
${ }^{28}$ Uriel Abulof, "Be Yourself! How Am I Not Myself?: II. Society and Politics: Between Essentialist and Existentialist Authenticity," Society 54, no. 6 (2017): 530-32, https://doi.org/10.1007/s12115-017-01830.

29 Jerome H. Barkow, "Prestige and the Ongoing Process of Culture Revision," ed. Joey T. Cheng, Jessica L. Tracy, and Cameron Anderson, The Psychology of Social Status, 2014, 29-45, https://doi.org/10.1007/978-1-4939-0867-7_2.

30 Jon K. Maner, "Dominance and Prestige: A Tale of Two Hierarchies," Current Directions in Psychological Science 26, no. 6 (2017): 526-31, https://doi.org/10.1177/0963721417714323.

${ }^{31}$ Shirley Le Penne, "Longing to Belong: Needing to Be Needed in a World in Need: III. Young
}

\section{Lusting after Another's Fortune (Envy)}

According to Van de Ven, two possible emotions may creep into a person's psyche when they sense that someone else is better than they are--admiration or envy, and oftentimes, it is envy that is in a commanding position. ${ }^{32}$ Envy is simply wanting what other persons have like their wealth, fame, good looks, success, and/or happiness. This may result either in positive or negative behavioral responses.

Feeling envious of what others have, taken positively is a benign form of envy. This is not destructive; in fact, it is a motivation to better oneself and to aspire to become like the person being envied, thus generating a form of envy known as emulative envy. ${ }^{33}$ But almost always, envy is a negative emotion that springs from comparison $^{34}$ and the result of feeling inferior to the persons being envied, who oftentimes are with the same level as the enviers. ${ }^{35}$ It increases awareness of what

Perspectives," Society 54, no. 6 (2017): 535-36, https://doi.org/10.1007/s12115-017-0185-y.

${ }^{32}$ Niels van de Ven, "Envy and Admiration: Emotion and Motivation Following Upward Social Comparison," Cognition and Emotion 31, no. 1 (2017): 193-200, https://doi.org/10.1080/02699931.2015.1087972.

33 Joseph H. Kupfer, "The Matrix of Envy in Amadeus," Quarterly Review of Film and Video 37, no. 7 (2020): 696-710, https://doi.org/10.1080/10509208.2020.1738195.

34 Jens Lange and Jan Crusius, "The Tango of Two Deadly Sins: The Social-Functional Relation of Envy and Pride," Journal of Personality and Social Psychology 109, no. 3 (2015): 453-72, https://doi.org/10.1037/pspi0000026.

35 Sara Protasi, "Varieties of Envy," Philosophical Psychology 29, no. 4 (2016): 535-49, https://doi.org/10.1080/09515089.2015.1115475. 
is lacking in oneself, as compared with others who are more fortunate, ${ }^{36}$ thus associating it with a negative positioning towards the persons being envied. ${ }^{37}$ It is rooted from ourselves and our own feelings of inadequacy and deprivation. ${ }^{38}$

According to Greenwood, there is this kind of envy called "existential envy that is secret, veiled and quiet, which is characterized by despair, rage, and hatred and wants the destruction of the one who is envied." ${ }^{39}$ Manifestations of this kind of envy could be gleaned from the quotes in the Cask of Amontillado below:

"You, who so well know the nature of my soul, will not suppose, however, that I gave utterance to a threat." 40

"It must be understood that neither by word nor deed had I given Fortunato cause to doubt my goodwill. I continued, as was my wont, to smile in his face, and he did not perceive that my smile now was at the thought of his immolation." 41

Evidently, Montressor's evil plan was concealed inside his smile as he

\footnotetext{
${ }^{36}$ Laura Quintanilla and Kristine Jensen de López, "The Niche of Envy: Conceptualization, Coping Strategies, and the Ontogenesis of Envy in Cultural Psychology," Culture \& Psychology 19, no. 1 (2013): 76-94, https://doi.org/10.1177/1354067X12464980.

37 Helena Wenninger, Christy MK Cheung, and Hanna Krasnova, "College-Aged Users Behavioral Strategies to Reduce Envy on Social Networking Sites: A Cross-Cultural Investigation," Computers in Human Behavior 97 (2019): 10-23, https://doi.org/10.1016/j.chb.2019.02.025.

${ }^{38}$ Kupfer, "The Matrix of Envy in Amadeus," 698.

39 Sallie Greenwood, "Envy in Relationships Between Maternal Dyads," The Family Journal 25, no. 1 (2017): 48-54, https://doi.org/10.1177/1066480716679650.

40 Poe, The Cask of Amontillado, 3.

${ }^{41}$ Poe, 3.
}

disguised as a friend in dire need of help. He pretended to be helpless but deep down inside he was fuming with anger and hatred. Such indignation and destructive thoughts and desires ${ }^{42}$ toward Fortunato were kept to himself that Fortunato did not have the slightest idea that Montressor, who smiled with malicious glee, was up to something. Besides, Fortunato would not have thought of such wicked plan against him because he, himself, was intoxicated not just by the wine he had drunk but by the trust and recognition of his talent given him by Montressor.

Another kind of envy was referred to by Greenie as Schadenfreude, ${ }^{43}$ which is the malicious type of envy and that takes pleasure in the misery of the person being envied. ${ }^{44}$ This can be seen in the following quotes while Montressor was stacking the tiers and after finishing Fortunato's tomb.

"I laid the second tier, and the third, and the fourth; and then I heard the furious vibrations of the chain. The noise lasted for several minutes, during which, that I might hearken to it with the more satisfaction." 45

\footnotetext{
${ }^{42}$ Gabriele Taylor, "Envy and Jealousy: Emotions and Vices," Midwest Studies in Philosophy 13 (1988): 233-49, https://doi.org/10.1111/j.14754975.1988.tb00124.x.

43 Keegan D. Greenier, "The Roles of Disliking, Deservingness, and Envy in Predicting Schadenfreude," Psychological Reports 124, no. 3 (2021): 1220-36, https://doi.org/10.1177/0033294120921358.

44 Jia Yuin Fam et al., "Benign and Malicious Envy Scale: An Assessment of Its Factor Structure and Psychometric Properties," Psychological Thought 13, no. 1 (2020): 66-84, https://doi.org/10.37708/psyct.v13i1.389.

${ }^{45}$ Poe, The Cask of Amontillado, 9.
} 
expressing his envy toward Fortunato but it gradually destroyed him, "As a moth gnaws a garment, so doth envy consume a man." In the story of "The Confession" by Guy de Maupassant, Marguerite confessed on her deathbed how she killed the man her elder sister was engaged to be married and whom she was secretly in love with.

"I was jealous, jealous! The moment of thy marriage approached...I became crazy. I said to myself, "He shall not marry Suzanne, no, I will not have it."'53

Marguerite was jealous of her sister every time she was with her fiancé and envious of the happiness the couple shared. On the part of Montressor, he may not be jealous but surely was envious of Fortunato because of the recognition accorded to him by the people belonging to their group in terms of his wine connoisseurship.

"I had seen you too; I was there, in the shrubbery. I was angry! If I could I should have killed you both." I said to myself" "He shall not marry Suzanne, never! He shall marry no one. I should be too unhappy." ${ }^{4}$

Just like Marguerite, Montressor plotted and carried out the crime he crafted in order to get even with the person who caused him untold pain and agony. The Christian faith teaches humankind to be happy for the happiness of others, but it is human nature to fall into the temptation of desiring and craving for

53 Guy de Maupassant, The Confession, from Eighty-Eight Short Stories, 1930, 4.

${ }^{54}$ Poe, The Cask of Amontillado, 4. something which others have. As Jesus told His disciples when He was tempted in the Garden of Gethsemane, "...The spirit is willing but the flesh is weak." 55 Montressor must have lived an unhappy life because there will be no room for long-lasting hatred for someone who is happy, content and loved.

The same is true with Madame Bovary, whose life was the exact opposite of what she dreamt of. She wanted to be rich and famous but got married to an unambitious middle-class doctor. This made her unhappy.

"She was not happy-she never had been. Whence came this insufficiency in life-this instantaneous turning to decay of everything on which she learned."

Unlike Montressor who murdered someone who caused his unhappiness due to envy, Madame Bovary committed suicide for not having the life she ever so wanted, which led her to run up huge debts after getting involved with extramarital affairs. Her actions and behavior were morally wrong because she violated the $6^{\text {th }}$ and the seventh commandments, "Thou shall not (self) murder" and "Thou shall not commit adultery," respectively.

Further, in Shakespeare's play, "Othello," lago's envy toward Cassi who got the promotion instead of him, drove him to craft revenge against Othello, the Moorish general of the Venetian armies,

55 ---"Matthew 26:41." American Bible Society."

${ }^{56}$ Gustave Flaubert, Madame Bovary: A Study of Provincial Life, ed. Dora Knowlton Ranous (New York: Brentano's Publishers, 1857), 361. 
by poisoning his mind to be suspicious of his wife Desdemona and Cassi.

Such desires and ambitions are innate in humans. While Marguerite felt remorseful and lago emotionally wounded, Montressor did not feel a tinge of regret, much less qualms for what he had done to Fortunato. In fact, he felt delighted that he could make Fortunato pay for causing him untold pain. Although envy may be viewed in a positive perspective that pushes an individual to overcome their feeling of inferiority and insecurity by being competitive, ${ }^{57}$ Montressor demonstrated a destructive type called malicious envy, ${ }^{58}$ which resulted in his wicked and abominable cruelty.

\section{Love Deprivation}

Love is said to be one of the basic needs and fundamental aspects of human existence. ${ }^{59}$ In the study conducted by Oved, a new framework was presented where he placed the "love needs" in Maslow's Hierarchy of Needs before safety needs. This strengthens the importance of love among humans. ${ }^{60}$

57 Sarah E. Hill and David M. Buss, "The Evolutionary Psychology of Envy," in Envy: Theory and Research, ed. Richard H. Smith, Series in Affective Science (New York: Oxford University Press, 2008), 60-70, https://doi.org/10.1093/acprof:oso/9780195327953. 003.0004.

58 Richard H. Smith and Sung Hee Kim, "Comprehending Envy," Psychological Bulletin 133, no. 1 (2007): 46-64, https://doi.org/10.1037/00332909.133.1.46.

59 Sven Nyholm, "Love Troubles: Human Attachment and Biomedical Enhancements," Journal of Applied Philosophy 32, no. 2 (2015): 190-202.

${ }^{60}$ Or Oved, "Rethinking the Place of Love Needs in Maslow's Hierarchy of Needs: III. Young
Many stories, fictional or otherwise, show the crucial role that love or the lack of it plays in the lives of humans. In fact, it can either make or break and build or destroy a person. The feeling of being loved is a manifestation of interpersonal relationships with others. ${ }^{61}$

According to Cousin, love is a composite of highly personal feelings of affection. ${ }^{62}$ Love exists only within specific relationships with other people. Evidently, in "The Cask of Amontillado," Montressor's actions and behavior displayed the lack of love in his life. There may not be any specific lines that would directly show it but living alone, not to mention the scheme which he plotted in its entirety, from the occasion to the location and the malicious and wicked means by which Fortunato was killed would speak of the lack of love.

Christians believe that we are created in the image of God," Then God said, Let us make humankind in our image according to our likeness ..." ${ }^{163}$ If then so, our actions must reflect the God who created us. Treating someone cruelly without feeling any qualms does not reflect the God who created us. Although no one is infallible, it is the feeling of

Perspectives," Society 54, no. 6 (2017): 537-38, https://doi.org/10.1007/s12115-017-0186-x.

61 Ronald R. Holden et al., "Response Surface Modeling of How Love Mitigates the Association between a Need to Belong and Suicidality," Personality and Individual Differences 134 (2018): 210-13, https://doi.org/10.1016/j.paid.2018.06.025.

62 Sarah Bernadette Cousins, 'Practitioners' Constructions of Love in Early Childhood Education and Care," International Journal of Early Years Education 25, no. 1 (2017): 16-29, https://doi.org/10.1080/09669760.2016.1263939.

63 ---"Genesis 1:26." American Bible Society." 
remorse after wrongdoing and the desire to repent and ask for God's forgiveness that will prove God's indwelling presence in us. Montressor was never guilt-ridden, as shown in the quote, "I must not only punish but punish with impunity. A wrong is unredressed when retribution overtakes its redresser." ${ }^{64}$

No trace or manifestations of love could be seen from his thoughts and actions. According to Nedelcu, a person who loves only does what is good and not what harms, nor what causes others to suffer and does something unjust. ${ }^{65}$ Eastman Susan Grove asserts that love "builds up." Evidently, Montressor literally destroyed Fortunato by burying him alive, stripping him off his dignity. ${ }^{66}$ Someone who does not have respect for others' dignity is less of a human because respecting the dignity of humans is treating them in ways consistent with their humanity.

\section{Conclusion}

Reviving the classic story, "The Cask of Amontillado," offers different meanings and interpretations apart from what already existed. This work explored themes associated with the human aspect of the characters' excessive esteem and penchant for fame or prestige (self-

\footnotetext{
${ }^{64}$ Poe, The Cask of Amontillado, 3.

65 Elena Nedelcu, "From Eros to Agape: A Multidisciplinary Perspective on Love," Romanian Review of Social Sciences 10, no. 18 (2020): 3948.

${ }^{66}$ Susan Grove Eastman, "Love's Folly: Love and Knowledge in 1 Corinthians," Interpretation: $A$ Journal of Bible and Theology 72, no. 1 (2018): 716, https://doi.org/10.1177/0020964317731325.
}

esteem), lusting after another's good fortune (envy), and love deprivation.

Noteworthy is the characteristic common to the themes that emerged from the content analysis of the story, and that is, all of them showed the negative or evil side of human nature that was accentuated and portrayed through the thoughts and actions of Montressor. It was unfortunate that no redeeming quality could be traced from Montressor. Although humans are wired to be unpleasant and ungodly, we, too, are inherently good-natured and kind because we are created in the image and likeness of God. Furthermore, that is something humanity should bring to mind and live by.

An important insight that can be gleaned from this work is that morals and value judgments as attributes of human nature should contribute to the human "being" and "becoming." In doing so, humans realize their purpose in life, they become at peace with themselves and others, and they take a step closer to their Creator, thus living life to the full and not allowing what is inside them to die while they live.

\section{References}

Aanstoos, Christopher M. "The Relevance of Humanistic Psychology." Journal of Humanistic Psychology 43, no. 3 (2003):

121-32. https://doi.org/10.1177/0022167803 043003010.

Abulof, Uriel. "Be Yourself! How Am I Not Myself?: II. Society and Politics: Between Essentialist and Existentialist Authenticity." Society 54, no. 6 (2017): 530-32. https://doi.org/10.1007/s12115-0170183-0. 
Baraban, Elena V. "The Motive for Murder in 'The Cask of Amontillado' by Edgar Allan Poe." Rocky Mountain Review of Language and Literature 58, no. 2 (2004): 47-62. https://doi.org/10.2307/1566552.

Barkow, Jerome $H$. "Prestige and the Ongoing Process of Culture Revision." Edited by Joey T. Cheng, Jessica L. Tracy, and Cameron Anderson. The Psychology of Social Status, (2014): 29-45. https://doi.org/10.1007/978-1-49390867-7_2.

Bland, Andrew M., and Eugene $M$. DeRobertis. "Humanistic Perspective." In Encyclopedia of Personality and Individual Differences, edited by Virgil ZeiglerHill and Todd K. Shackelford, 1-19. Cham: Springer International Publishing, 2019. https://doi.org/10.1007/978-3-31928099-8 1484-2.

Cousins, Sarah Bernadette. "Practitioners' Constructions of Love in Early Childhood Education and Care." International Journal of Early Years Education 25, no. 1 (2017): 16-29. https://doi.org/10.1080/09669760.20 16.1263939.

Cuţitaru, Codrin Liviu. "The Art of Dissimulation. The Good Christian vs. the Loyal Freemason." Philologica Jassyensia 13, no. 2 (2017): 203-9.

De Vooght, Edward, and Guylian Nemegeer. "Reading and Analysing Short Story Collections. An Empirical Study of Readers' Interpretation Process of Benni's II Bar Sotto II Mare." Language and Literature: International Journal of Stylistics, (2021). https://doi.org/10.1177/0963947021 1047817.

DiSanza, Raymond. "On Memory, Forgetting, and Complicity in 'The Cask of Amontillado." The Edgar Allan Poe Review 15, no. 2 (2014): 194-204. https://doi.org/10.5325/edgallpoerev .15.2.0194.

Eastman, Susan Grove. "Love's Folly: Love and Knowledge in 1 Corinthians." Interpretation: $A$ Journal of Bible and Theology 72, no. 1 (2018): 7-16. https://doi.org/10.1177/0020964317 731325.

Ellemers, Naomi, Jojanneke van der Toorn, Yavor Paunov, and Thed van Leeuwen. "The Psychology of Morality: A Review and Analysis of Empirical Studies Published From 1940 Through 2017." Personality and Social Psychology Review 23, no. 4 (2019): $332-66$. https://doi.org/10.1177/1088868318 811759.

Etzioni, Amitai. "The Moral Wrestler: Ignored by Maslow: I. Foundations." Society 54, no. 6 (2017): 512-19. https://doi.org/10.1007/s12115-0170200-3.

Fam, Jia Yuin, Caroline Yu Li Yap, Sri Bala Murugan, and Tziyun Lee. "Benign and Malicious Envy Scale: An Assessment of Its Factor Structure and Psychometric Properties." Psychological Thought 13, no. 1 (2020): 66-84. https://doi.org/10.37708/psyct.v13i1. 389.

Ferreira, Kirla, and Delane Botelho. "(Un)Deservingness Distinctions Impact Envy Subtypes: Implications for Brand Attitude and Choice." Journal of Business Research 125 (2021): 89-102. https://doi.org/10.1016/j.jbusres.202 0.12 .008 .

Fialho, Olivia. "What is Literature for? The Role of Transformative Reading." Edited by Anezka Kuzmicova. Cogent Arts \& Humanities 6, no. 1 (2019): 1-16. https://doi.org/10.1080/23311983.20 19.1692532 .

Flaubert, Gustave. Madame Bovary: $A$ Study of Provincial Life. Edited by 
Dora Knowlton Ranous. New York: Brentano's Publishers, 1857.

Greenier, Keegan D. "The Roles of Disliking, Deservingness, and Envy in Predicting Schadenfreude." Psychological Reports 124, no. 3 (2021): 1220-36. https://doi.org/10.1177/0033294120 921358.

Greenwood, Sallie. "Envy in Relationships Between Maternal Dyads." The Family Journal 25, no. 1 (2017): 4854. https://doi.org/10.1177/1066480716 679650.

Hill, Sarah E., and David M. Buss. "The Evolutionary Psychology of Envy." In Envy: Theory and Research, edited by Richard H. Smith, 60-70. Series in Affective Science. New York: Oxford University Press, 2008. https://doi.org/10.1093/acprof:oso/9 780195327953.003.0004.

Hinze, Eike. "Envy: How to Interpret a Mortal Sin?" Romanian Journal of Psychoanalysis 13, no. 2 (2020): 93-116. https://doi.org/10.2478/rjp2020-0018.

Holden, Ronald R., Christine E. Lambert, Genevieve Bianchini, Robbie E. Wong, Shahrukh Towheed, Christy Yeung, and G. Cynthia Fekken. "Response Surface Modeling of How Love Mitigates the Association between a Need to Belong and Suicidality." Personality and Individual Differences 134 (2018): 210-13.

https://doi.org/10.1016/j.paid.2018.0 6.025 .

Hsieh, Hsiu-Fang, and Sarah E. Shannon. "Three Approaches to Qualitative Content Analysis." Qualitative Health Research 15, no. 9 (2005): 1277-88.

https://doi.org/10.1177/1049732305 276687.

Krippendorff, Klaus. Content Analysis: An Introduction to Its Methodology. Thousand Oaks: SAGE, 2013.
Kupfer, Joseph H. "The Matrix of Envy in Amadeus." Quarterly Review of Film and Video 37, no. 7 (2020): 696710.

https://doi.org/10.1080/10509208.20 20.1738195 .

Lange, Jens, and Jan Crusius. "The Tango of Two Deadly Sins: The Social-Functional Relation of Envy and Pride." Journal of Personality and Social Psychology 109, no. 3 (2015): 453-72. https://doi.org/10.1037/pspi0000026.

Le Penne, Shirley. "Longing to Belong: Needing to Be Needed in a World in Need: III. Young Perspectives." Society 54, no. 6 (2017): 535-36. https://doi.org/10.1007/s12115-0170185-y.

Lewis-Beck, Michael, Alan Bryman, and Tim Futing Liao. The SAGE Encyclopedia of Social Science Research Methods. Thousand Oaks: Sage Publications, Inc., 2004. https://doi.org/10.4135/9781412950 589.

Maner, Jon K. "Dominance and Prestige: A Tale of Two Hierarchies." Current Directions in Psychological Science 26, no. 6 (2017): 526-31. https://doi.org/10.1177/0963721417 714323.

Maupassant, Guy de. The Confession, from Eighty-Eight Short Stories, 1930.

Milić, Andrea. "Envy - an Unwanted, yet Unavoidable and Necessary Emotion." Psihologijske Teme 28, no. 2 (2019): 355-75. https://doi.org/10.31820/pt.28.2.7.

Nedelcu, Elena. "From Eros to Agape: A Multidisciplinary Perspective on Love." Romanian Review of Social Sciences 10, no. 18 (2020): 39-48.

Niveau, Noémie, Boris New, and Marine Beaudoin. "Self-Esteem Interventions in Adults - A Systematic Review and MetaAnalysis." Journal of Research in Personality 94 (2021): 104-31. 
https://doi.org/10.1016/j.jrp.2021.10 4131.

Nyholm, Sven. "Love Troubles: Human Attachment and Biomedical Enhancements." Journal of Applied Philosophy 32, no. 2 (2015): 190202.

Oved, Or. "Rethinking the Place of Love Needs in Maslow's Hierarchy of Needs: III. Young Perspectives." Society 54, no. 6 (2017): 537-38. https://doi.org/10.1007/s12115-0170186-x.

Poe, Edgar Allan. The Cask of Amontillado. Taiwan: Hyweb Technology Co. Ltd., 2011.

Protasi, Sara. "Varieties of Envy." Philosophical Psychology 29, no. 4 (2016): 535-49. https://doi.org/10.1080/09515089.20 15.1115475.

Pugh, Syrithe. "Adonis and Literary Immortality in Pastoral Elegy." In Conversations: Classical and Renaissance Intertextuality, edited by Syrithe Pugh. Manchester: Manchester University Press, 2020. https://doi.org/10.7765/9781526152 688.

Quintanilla, Laura, and Kristine Jensen de López. "The Niche of Envy: Conceptualization, Coping Strategies, and the Ontogenesis of Envy in Cultural Psychology." Culture \& Psychology 19, no. 1 (2013): $\quad$ 76-94. https://doi.org/10.1177/1354067X12 464980.

Ray, Caitlin. Revenge (Essential Literary Themes). Minneapolis, Minnesota: Abdo Publishing, 2015.

Read, Daniel. "The Five Games of $\mathrm{Mr}$ Edgar Allan Poe: A Study of Strategic Thought in 'The Purloined Letter." Rationality and Society 32, no. 4 (2020): 369-401. https://doi.org/10.1177/1043463120 961779
Reeves, Robert, John Gountas, Sandra Gountas, and Lucy Moran. "Desire for Fame: Scale Development and Association with Personal Goals and Aspirations." Psychology and Marketing 29, no. 9 (2012): 680-89. https://doi.org/10.1002/mar.20554.

Schreier, Margrit. Qualitative Content Analysis in Practice. London: SAGE Publications, 2012.

Smith, Richard H., and Sung Hee Kim. "Comprehending Envy." Psychological Bulletin 133, no. 1 (2007): $46-64$. https://doi.org/10.1037/00332909.133.1.46.

Steinbeis, Nikolaus, and Tania Singer. "The Effects of Social Comparison on Social Emotions and Behavior during Childhood: The Ontogeny of Envy and Schadenfreude Predicts Developmental Changes in EquityRelated Decisions." Journal of Experimental Child Psychology 115, no. 1 (2013): 198-209. https://doi.org/10.1016/j.jecp.2012.1 1.009 .

Taylor, Gabriele. "Envy and Jealousy: Emotions and Vices." Midwest Studies in Philosophy 13 (1988): 233-49.

https://doi.org/10.1111/j.1475-

4975.1988.tb00124.x.

Ven, Niels van de. "Envy and Admiration: Emotion and Motivation Following Upward Social Comparison." Cognition and Emotion 31, no. 1 (2017): 193-200. https://doi.org/10.1080/02699931.20 15.1087972 .

Wenninger, Helena, Christy MK Cheung, and Hanna Krasnova. "CollegeAged Users Behavioral Strategies to Reduce Envy on Social Networking Sites: A Cross-Cultural Investigation." Computers in Human Behavior 97 (2019): 10-23. https://doi.org/10.1016/j.chb.2019.0 2.025 
Whatley, Rehana. "Confession within A Confession: Poe's Brave New World in 'The Cask of Amontillado." Journal of Global Intelligence \& Policy 5, no. 7 (2012): 56-59. 